\title{
Benralizumab: A New Approach for the Treatment of Severe Eosinophilic Asthma
}

\author{
Dávila González I', Moreno Benítez F², Quirce S33 \\ 'Allergy Service, University Hospital of Salamanca, School of Medicine, University of Salamanca, Salamanca, Spain \\ ${ }^{2}$ Immunology and Allergy Unit, Clínica Lobatón, Cádiz, Spain; Grupo Asociado AS03 Inmunología y Alergia, associated with IN-C016 INIBICA \\ (Instituto Biomédico de Cádiz), Cádiz, Spain \\ ${ }^{3}$ Department of Allergy, Hospital Universitario La Paz Institute for Health Research (IdiPAZ) and CIBER of Respiratory Diseases (CIBERES), Madrid, \\ Spain
}

J Investig Allergol Clin Immunol 2019; Vol. 29(2): 84-93

doi: 10.18176/jiaci.0385

\begin{abstract}
Eosinophilic asthma is the most common phenotype of severe asthma. It is characterized by abnormal production and release of type 2 cytokines from T helper type $2\left(T_{H} 2\right)$ lymphocytes and type 2 innate lymphoid cells, such as IL-5. This leads to a persistent increase and activation of eosinophils in blood and the airways despite treatment with high-dose inhaled corticosteroids. Eosinophil differentiation, survival, and activation are preferentially regulated by IL-5, a cytokine that binds to the IL-5 receptor (IL-5R), which is located on the surface of eosinophils or basophils and plays a critical role in the pathogenesis and severity of asthma. Benralizumab is a monoclonal antibody that binds to IL-5R via its Fab domain, blocking the binding of IL-5 to its receptor and resulting in inhibition of eosinophil differentiation and maturation in bone marrow. In addition, this antibody is able to bind through its afucosylated Fc domain to the RIIla region of the Fcy receptor on NK cells, macrophages, and neutrophils, thus strongly inducing antibody-dependent, cell-mediated cytotoxicity in both circulating and tissue-resident eosinophils. This double function of benralizumab induces almost complete fast and maintained depletion of eosinophils that is much greater than that induced by other monoclonal antibodies targeting the IL-5 pathway, such as mepolizumab and reslizumab. This review focuses on benralizumab as an alternative to other agents targeting the IL-5 pathway in the treatment of eosinophilic asthma.
\end{abstract}

Key words: Eosinophils. Basophils. ILC-2. Exacerbations. Phenotype.

\section{Resumen}

El asma eosinofílica es el fenotipo más común del asma grave. Se caracteriza por una producción y liberación anómala de citocinas de tipo 2, como la IL-5, por los linfocitos T colaboradores de tipo 2 (Th2) y las células linfoides innatas de tipo 2 (ILC-2). Con ello se activan los eosinófilos y se incrementa su número en sangre y vías respiratorias, a pesar del tratamiento con dosis altas de corticosteroides inhalados. La diferenciación, supervivencia y activación de los eosinófilos está regulada principalmente por la IL-5, una citocina que se une a su receptor (IL-5R), situado en la superficie de eosinófilos y basófilos, y que desempeña un papel fundamental en la patogénesis y gravedad del asma. El benralizumab es un anticuerpo monoclonal que se une al IL-5R a través de su dominio Fab, bloqueando la unión de la IL-5 a su receptor, lo que provoca una inhibición de la diferenciación y maduración de los eosinófilos en la médula ósea. Además, este anticuerpo es capaz de unirse a través de su dominio Fc afucosilado a la región RIlla del receptor Fc $\gamma$ situado en células NK, macrófagos y neutrófilos, induciendo así una intensa citotoxicidad mediada por células dependiente de anticuerpos (ADCC), tanto de los eosinófilos circulantes como de los residentes en tejidos. Esta doble función del benralizumab induce una disminución casi completa de los eosinófilos de una forma rápida y mantenida, mucho mayor a la inducida por otros anticuerpos monoclonales dirigidos contra la IL-5, como el mepolizumab o el reslizumab. Esta revisión se centra en describir el uso del benralizumab en el tratamiento del asma eosinofílica como una alternativa a otros agentes que actúan directamente sobre la IL-5.

Palabras clave: Eosinófilos. Basófilos. ILC-2. Exacerbaciones. Fenotipo. 


\section{Introduction}

According to the Global Initiative for Asthma (GINA), asthma is a heterogeneous disease that is usually characterized by chronic airway inflammation and defined by respiratory symptoms such as wheeze, shortness of breath, chest tightness, and cough, which vary over time and in intensity, together with variable expiratory airflow limitation [1]. Variations are often triggered by factors such as exercise, allergen or irritant exposure, changes in weather, and viral respiratory infections [2]. Moreover, asthma is considered a heterogeneous syndrome resulting from complex interactions between environmental and genetic factors. These interactions result in very diverse clinical presentations and phenotypes [3]

The main features of asthma include airway inflammation and remodeling, bronchial obstruction, airway hyperresponsiveness, and variation or fluctuation in symptoms and lung function over time [2]. Even if the clinical spectrum of asthma is highly variable, inflammation of the airways is a common pathological feature, although the relationship between the severity of asthma and the intensity of inflammation has not been consistently established [4]. In most asthmatic patients, the characteristic inflammatory pattern includes an increase in the number of type 2 helper $\mathrm{T}\left(\mathrm{T}_{\mathrm{H}} 2\right)$ lymphocytes, type 2 innate lymphoid cells (ILC-2s), and natural killer (NK) cells, as well as mast cells, basophils, and activated eosinophils, which release mediators that cause symptoms of disease $[5,6]$.

Type 2 immune reactions are categorized as adaptive immune responses with differentiated $T_{H}$ cells taking center stage, driving eosinophil recruitment and immunoglobulin production via secretion of a distinct repertoire of cytokines that include interleukin (IL) 4, IL-5, and IL-13. In addition, ILC-2s have the capacity to secrete type 2 cytokines in the absence of adaptive immunity. These cells respond to stress signals and to the so-called alarmins, ie, IL-33, IL-25, and thymic stromal lymphopoietin, which drive ILC-2 growth and cytokine production. In some types of asthma, eosinophilic inflammation is controlled by these cells, which act together with basophils [7,8].

Severe asthma is characterized by the need for treatment with several drugs at high doses and can be controlled and uncontrolled [9]. Severe uncontrolled asthma is defined as asthma that continues to be poorly controlled despite treatment with a combination of high-dose inhaled corticosteroids (ICSs) and long-acting $\beta_{2}$-agonists (LABAs) and/or other controller drugs in the past year, or oral corticosteroids (OCSs) for at least 6 months during the same period [10]. The prevalence of uncontrolled severe persistent asthma has been estimated at $3.9 \%$ of the asthmatic population [11]. Depending on the natural history of the disease, pathobiology, clinical characteristics, pulmonary function, and response to therapy, studies based on cluster analysis have identified different asthma phenotypes. The 4 phenotypes that have shown the greatest consistency in studies of severe adult asthma are allergic asthma, late-onset eosinophilic asthma, asthma associated with obesity, and lateonset neutrophilic asthma [12-14]. Their identification could prove difficult because their characteristics often overlap and may even change over time. Although phenotype-guided treatment is available, no strong relationship has been found to date between specific pathological features and particular clinical patterns or responses to treatment [15].

According to the step-based approach to therapy, severe uncontrolled asthma is treated according to steps 5-6 of the Spanish Guidelines for Asthma Management (GEMA, Guia Española para el Manejo del Asma) and step 5 of the GINA guidelines $[1,2]$. In addition, biological drugs targeting the IL-5 pathway can be used for the treatment of uncontrolled severe eosinophilic asthma. Currently, mepolizumab and reslizumab, monoclonal antibodies against IL-5, and benralizumab, a monoclonal antibody targeting the $\alpha$ chain of the IL-5 receptor (IL-5R $\alpha$ ), are licensed as additional treatment in adult patients ( $\geq 18$ years) with severe uncontrolled persistent eosinophilic asthma [16-28]. This review focuses on the use of benralizumab in the treatment of eosinophilic asthma.

\section{Characteristics and Treatment of Eosinophilic Asthma}

Eosinophilic asthma is the most common asthmatic phenotype, accounting for over $50 \%$ of cases of severe asthma. It is characterized by abnormal production of type 2 cytokines produced by $\mathrm{T}_{\mathrm{H}} 2$ lymphocytes and ILC-2s, resulting in a persistent increase in eosinophils in blood and the airways (sputum, bronchoalveolar lavage, and bronchial mucosa or submucosa) [29-31]. Blood and sputum eosinophilia have been associated with more severe disease, worse disease control, and a higher risk of exacerbations [32].

Severe eosinophilic asthma should fulfill the diagnostic criteria for severe asthma and demonstrate a persistent increase in eosinophils in blood and/or the airways [31]. Although there is no consensus on eosinophil cut-off levels, a blood eosinophil count of $0.22-0.27 \times 10^{9} / \mathrm{L}$ is used to differentiate between eosinophilic and noneosinophilic asthma with a sensitivity of $78 \%-86 \%$ [33]. Elevated blood eosinophil levels are associated with decreased lung function parameters (forced expiratory volume in 1 second $\left[\mathrm{FEV}_{1}\right]$ and peak expiratory flow [PEF]) [34]. In addition, increased blood eosinophil counts $\left(0.3 \times 10^{9} / \mathrm{L}\right)$, along with increased fractional exhaled nitric oxide (FeNO) levels, are associated with more poorly controlled asthma [35]. Furthermore, elevated blood eosinophil counts $\left(>0.4 \times 10^{9} / \mathrm{L}\right)$ are correlated with sputum eosinophils in mild to severe asthma and linked to a higher rate of severe asthma exacerbations [36,37]. A recent report has shown that blood eosinophilia has good sensitivity but low specificity for detection of eosinophilia in sputum, even in patients treated with inhaled corticosteroids, in contrast with FeNO, whose sensitivity decreases in patients treated with corticosteroids [38].

Eosinophils represent approximately $1 \%-5 \%$ of peripheral blood leukocytes. They are produced in bone marrow, and their differentiation, survival, and activation are mainly regulated by IL-5 $[39,40]$. However, it has been suggested that local differentiation, maturation, and activation of eosinophils in the airways may contribute to persistent sputum eosinophilia in prednisone-dependent patients who may have normal blood eosinophil counts. This local event may be driven by IL-5 and IL-13, which are produced locally by relatively corticosteroid- 
insensitive ILC-2s [41]. Eosinophils leave the bloodstream and migrate to inflamed tissues because of the effect of surface receptors (IL-5R $\alpha, \mathrm{CC}$-chemokine receptor 3, cysteinyl leukotriene type 1 receptor, and $\alpha 4 \beta 1$ and $\alpha 4 \beta 7$ integrins) and the influence of several cytokines and chemokines such as IL-4, IL-5, and IL-13 and CCL11, CCL24, and CCL26 (also known as eotaxins 1,2 , and 3 , respectively) $[39,40,42]$.

Eosinophils have different functions, such as tissue repair and remodeling, angiogenesis, clearance of parasites, metabolic homeostasis, immune surveillance, and immune cell activation. In addition, eosinophils and their mediators participate in the pathophysiology of a variety of diseases, including allergic asthma $[39,40,43]$. Although the main pathway for the recruitment of eosinophils into blood and airways includes $\mathrm{T}_{\mathrm{H}} 2$ cells and the production and release of IL-4, IL-5, and IL-13, mounting evidence suggests that other pathways and cells might contribute. Thus, ILC-2s express both IL-5 and IL-13 and are thought to be intrinsically resistant to corticosteroids [41].

By binding to the IL-5R $\alpha$ chain of the IL5 receptor (IL$5 \mathrm{R}), \mathrm{IL}-5$ is a $\mathrm{T}_{\mathrm{H}} 2$ cytokine involved in the differentiation, maturation, migration, activation, and prevention of apoptosis of eosinophils [39]. In addition, IL-5 appears to modulate the development of basophils and mast cells, enhancing the release of mediators (such as leukotrienes) via the engagement of IL-5R $[39,44]$. IL-5 is produced mainly by $\mathrm{T}_{\mathrm{H}} 2$ cells, CD $34^{+}$ progenitor cells, invariant NK T cells, mast cells, ILC-2s, basophils, and eosinophils themselves [39,44]. IL-5 levels are increased in eosinophilic asthma [45].

Biological drugs targeting either eosinophils or the IL-5 pathway have been developed for the treatment of severe uncontrolled eosinophilic asthma, irrespective of the presence of allergy. On the one hand, some biologic therapies (eg, bertilimumab) block recruitment of eosinophils, thus preventing the accumulation of these cells in tissues [46]. In addition, drugs targeting the IL-5 pathway may be used; these bind directly to IL-5 (mepolizumab and reslizumab) and to IL-5R $\alpha$ (benralizumab) (Figure) [16-28]. By blocking the

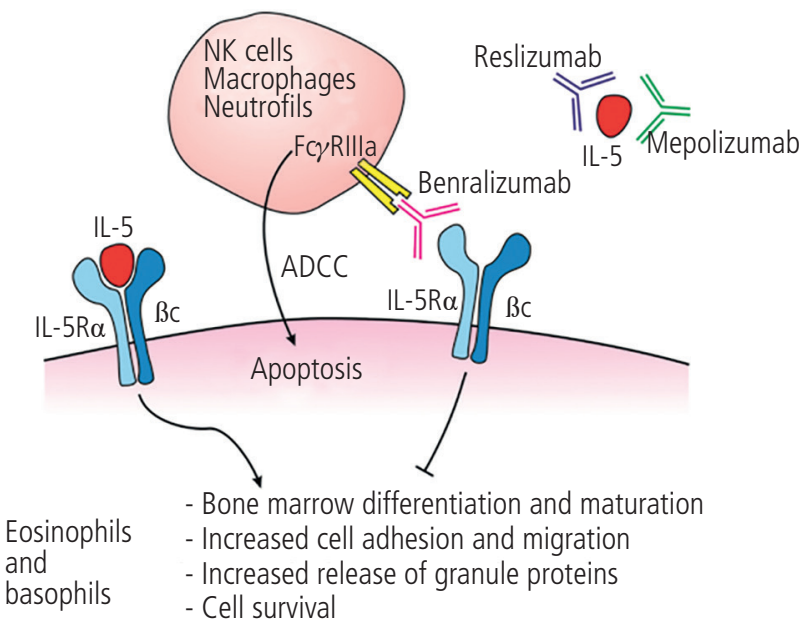

Figure. Mechanism of action of benralizumab and other anti-IL-5 drugs. ADCC indicates antibody-dependent cell-mediated cytotoxicity. interaction between IL-5 and its receptor, the eosinophil count in blood and the airways decreases, as does survival of these cells, ultimately resulting in clinical improvement.

\section{Characteristics of Benralizumab}

Benralizumab is a humanized IgG1 $\kappa$ monoclonal antibody. It has been approved as add-on maintenance treatment in adult patients with severe eosinophilic asthma that is inadequately controlled despite high-dose ICSs plus a LABA [47]. The antibody is able to bind to IL-5R $\alpha$ via its Fab domain with high affinity and specificity, thus blocking binding of IL-5 to its receptor, which is located on human eosinophils and basophils. As a result, the proliferation and maturation of these cells in bone marrow is affected, as are migration, activation, and survival at the sites of inflammation (Figure) [48]. The Administration of benralizumab produces a dramatic reduction in eosinophil counts in blood, airway mucosa, and sputum, as well as inhibition of eosinophil differentiation and maturation in bone marrow.

In contrast with the anti-IL5 monoclonal antibodies mepolizumab and reslizumab, benralizumab lacks a fucose sugar residue in the $\mathrm{CH} 2$ region of the $\mathrm{Fc}$ domain. This afucosylation enables benralizumab to bind with high affinity to the RIIIa region of the Fc $\gamma$ receptor found on NK cells, macrophages, and neutrophils, thus strongly inducing antibody-dependent cell-mediated cytotoxicity of eosinophils and basophils (Figure) [49]. Consequently, benralizumab can target and deplete both circulating and tissue-resident eosinophils. Mepolizumab and reslizumab only block the activation of eosinophils by neutralizing circulating IL-5 without inducing apoptosis of resident eosinophils [48]. Apoptosis has the advantage of preventing the release of toxic granules.

Acting directly on a specific cell receptor instead of indirectly through a mediator enables more effective depletion of target cells. Thus, benralizumab induces fast and almost complete depletion of eosinophils ( $>95 \%$ ), which is higher than that induced by mepolizumab $(84 \%)$ and reslizumab (82\%) [16-28]. This almost complete depletion of blood eosinophils occurs within 24 hours of the first dose. The effect is maintained for 12 weeks after a single dose ranging from 0.3 to $3 \mathrm{mg} / \mathrm{kg}$ [50]. The decrease in blood eosinophils is accompanied by a reduction in serum levels of eosinophilderived neurotoxin and eosinophil cationic protein and a decrease in blood basophils. In addition, no changes were observed in levels of tumor necrosis factor and interferon gamma, whereas serum levels of IL-5, CCL11, and CCL24 were significantly higher for benralizumab than for placebo $(P<.05)[51,52]$.

The effect of benralizumab on the eosinophils of the airway mucosa was evaluated in a 12 -week, double blind, randomized, placebo-controlled phase 1 study of asthmatic patients with elevated eosinophil counts in sputum (at least $2.5 \%$ ). Eighty-four days after subcutaneous administration of $100 \mathrm{mg}$ or $200 \mathrm{mg}$ of benralizumab, a median reduction of $95.8 \%$ in airway eosinophil counts in bronchial biopsies was observed (46.7\% with placebo, $P=.06$ ), as was an $89.9 \%$ 
decrease in the eosinophil count in sputum [53]. Similar results were observed more recently with the approved subcutaneous dose of benralizumab (30 mg), resulting in an almost complete depletion of eosinophils in both blood and sputum after 12 weeks of treatment [54,55].

\section{Optimal Dose of Benralizumab}

A pilot trial on the safety, pharmacokinetics, and biologic activity of benralizumab that assessed intravenous doses $(0.0003-3 \mathrm{mg} / \mathrm{kg})$ administered to patients with mild atopic asthma found that peripheral blood eosinophil levels decreased in a dose-dependent manner, reaching eosinopenia after $8-12$ weeks with dosages $>0.03 \mathrm{mg} / \mathrm{kg}$ and an acceptable safety profile [50]. In addition, a phase 1 study evaluated the safety and tolerability of benralizumab, as well as its effect on eosinophil counts in biopsies of the airway mucosa from patients with atopic asthma [53]. Twenty-seven adults with asthma and $\geq 2.5 \%$ of eosinophils in sputum were allocated to 2 cohorts. The first cohort received a single intravenous dose of benralizumab (1 mg/kg), and the second cohort received the drug subcutaneously (100 mg or $200 \mathrm{mg}$ ). After 21 days, intravenous treatment decreased the eosinophil count in sputum by $18.7 \%$, whereas the subcutaneous dosage achieved a reduction of $89.9 \%$. On the other hand, both treatment strategies decreased blood eosinophil counts by $100 \%$. The authors concluded that a single intravenous dose and multiple subcutaneous dosing of benralizumab led to reduced eosinophil counts in airway mucosa/submucosa and sputum, and a suppression of bone marrow eosinophil counts, resulting in a significant reduction in eosinophilic airway inflammation compared with placebo [53].

A randomized, controlled, double-blind, dose-ranging phase $2 \mathrm{~b}$ study assessed the efficacy and safety of benralizumab in adults with uncontrolled eosinophilic asthma despite using medium or high-dose ICSs and a LABA and 2-6 exacerbations in the previous year [56]. Eligible participants were stratified by their eosinophilic status based on the eosinophil/lymphocyte and eosinophil/neutrophil index and FeNO levels (cut-off point $<$ or $\geq 50 \mathrm{ppb}$ ). Eosinophilic

Table 1. Summary of Phase 3 Trials Evaluating the Efficacy of Benralizumab in the Treatment of Severe Uncontrolled Eosinophilic Asthma

\begin{tabular}{|c|c|c|c|}
\hline Study (Year) & Duration & $\begin{array}{l}\text { No. of } \\
\text { Patients }\end{array}$ & $\begin{array}{l}\text { Main } \\
\text { Results }\end{array}$ \\
\hline SIROCCO (2016) [28] & 48 wk & 1205 & $\begin{array}{l}\downarrow \text { asthma } \\
\text { exacerbations } \\
\uparrow \text { FEV }_{1}\end{array}$ \\
\hline CALIMA (2016) [27] & $56 \mathrm{wk}$ & 1306 & $\begin{array}{l}\downarrow \text { asthma } \\
\text { exacerbations } \\
\uparrow \mathrm{FEV}_{1}\end{array}$ \\
\hline ZONDA (2017) [55] & $28 w k$ & 220 & $\begin{array}{l}\downarrow \text { OCS needs } \\
\downarrow \text { asthma } \\
\text { exacerbations }\end{array}$ \\
\hline
\end{tabular}

Abbreviations: $\mathrm{FEV}_{1}$, forced expiratory volume in 1 second; OCS, oral corticosteroid. patients were randomized to receive placebo or benralizumab ( $2 \mathrm{mg}, 20 \mathrm{mg}$, or $100 \mathrm{mg}$ ). Noneosinophilic patients received placebo or $100 \mathrm{mg}$ benralizumab. Treatment was given as 2 subcutaneous injections every 4 weeks for the first 3 doses, then every 8 weeks, for 1 year. At the 100-mg dose, benralizumab was found to reduce exacerbation rates in the eosinophilic cohort by $41 \%(P=.096)$ compared with placebo, but not at the $2-\mathrm{mg}(P=.781)$ or $20-\mathrm{mg}(P=.173)$ dose. In patients with a baseline blood eosinophil cut-off of at least 300 cells $/ \mu \mathrm{L}$, exacerbation rates were reduced by $57 \%$ in the benralizumab 20 -mg group $(P=.015)$, and by $43 \%$ in the $100-\mathrm{mg}$ group $(P=.049)$. The authors concluded that the dose-response plateau of benralizumab ranges between $20 \mathrm{mg}$ and $100 \mathrm{mg}$. In the group of noneosinophilic patients who received $100 \mathrm{mg}$ of benralizumab, the exacerbation rate was reduced by $22 \%$, although the difference did not reach statistical significance $(P=.284)$ [56].

\section{Efficacy Trials With Benralizumab}

The efficacy and safety of benralizumab in the treatment of severe uncontrolled eosinophilic asthma was evaluated in 3 phase 3 randomized, double-blind, placebo-controlled, parallel-group clinical trials with a duration of 28-56 weeks in patients aged $12-75$ years $[27,28,55]$. A summary of these trials is shown in Table 1. The SIROCO and CALIMA trials examined the effects of the monoclonal antibody on long-term exacerbations in both adults and adolescents ( $\geq 12$ years), while the ZONDA trial evaluated the reduction in OCS use following antibody administration in adults.

In all 3 studies, patients were randomized to 3 groups. In 2 groups, benralizumab was administered at a dose of $30 \mathrm{mg}$ once every 4 weeks for the first 3 doses and then every 4 or 8 weeks, respectively, for each group. The third group received placebo. Although 2 dosage regimens of benralizumab were studied in the 3 trials, the following results correspond mainly to the recommended dose of benralizumab: $30 \mathrm{mg}$ every 4 weeks for the first 3 doses and then every 8 weeks [47]. No additional benefit was observed with the more frequent administration schedule (every 4 weeks) $[27,28,55]$.

\subsection{SIROCCO and CALIMA: Exacerbation Trials}

The SIROCCO [28] and CALIMA [27] trials included a total of 2511 patients with severe uncontrolled asthma. The mean age of the patients was 49 years, and $64 \%$ were women. Patients had a history of $\geq 2$ asthmatic exacerbations (between 2.7-3.0) requiring oral or systemic corticosteroids in the previous 12 months, a score $\geq 1.5$ on the Asthma Control Questionnaire-6 (ACQ-6) at baseline, and a mean predicted prebronchodilator $\mathrm{FEV}_{1}$ of $57.5 \%$ despite regular treatment with high-dose ICSs (SIROCCO) or a combination of medium- or high-dose ICSs and a LABA (CALIMA). The primary objective of these 2 trials was the annual rate of asthma exacerbations in patients with a baseline blood eosinophil count $\geq 300$ cells/ $\mu \mathrm{L}$ who were receiving a combination of high-dose ICSs and a LABA. An exacerbation was defined as a worsening of asthma requiring oral/systemic corticosteroids for at least 3 days or emergency department visits requiring oral/systemic 
corticosteroids, hospitalization, or both emergency visits and hospitalization. For patients receiving oral maintenance corticosteroids, exacerbations were defined as a temporary increase in the stable dose of OCSs/systemic corticosteroids for at least 3 days or a single injectable dose of extended-release corticosteroids.

In both trials, the rate of annual exacerbations decreased significantly in patients treated with benralizumab compared with those receiving placebo when the blood eosinophil count was $\geq 300$ cells $/ \mu \mathrm{L}$. A decrease in the rate of exacerbations was observed irrespective of the baseline eosinophil count ( $\geq 300$ eosinophils $/ \mu \mathrm{L}$, reduction of $51 \%$ in SIROCCO at 48 weeks $[P<.0001]$ or $28 \%$ in CALIMA at 56 weeks $[P=.0188]$ relative to placebo; $<300$ eosinophils $/ \mu \mathrm{L}$, reduction of $17 \%$ in SIROCCO at 48 weeks $[P=.269]$ or $40 \%$ in CALIMA at 56 weeks $[P=.0048]$ relative to placebo).

The beneficial effect on $\mathrm{FEV}_{1}$ could be measured from 4 weeks onwards and was maintained until the end of the treatment. The difference in least-squares mean change from baseline between the benralizumab and placebo cohorts was $0.159 \mathrm{~L}(0.068-0.249 ; P=.0006)$ in SIROCCO, $0.116 \mathrm{~L}(0.028-0.204 ; P=.0102)$ in CALIMA in patients with $<300$ eosinophils $/ \mu \mathrm{L}, 0.102 \mathrm{~L}(0.003-0.208 ; P=.568)$ in SIROCCO, and $-0.015 \mathrm{~L}(-0.127$ to $0.096 ; P=.7863)$ in CALIMA in patients with $\geq 300$ eosinophils $/ \mu \mathrm{L}$.

When the results of both studies were pooled, there was a numerically greater decrease in the rate of exacerbations and a greater improvement in $\mathrm{FEV}_{1}$ when blood eosinophil count was increased at baseline. An increase in baseline eosinophil count was a possible predictor of better response to treatment, particularly for $\mathrm{FEV}_{1}$.

The rate of exacerbations requiring hospitalization or emergency department visits in patients treated with benralizumab, compared with those receiving placebo, was 0.09 vs $0.25(P<.001)$ in SIROCCO and 0.12 vs $0.10(P=.538)$ in CALIMA. It is important to note that in the CALIMA study, the low number of episodes of exacerbations requiring hospitalization or emergency visits in the placebo group precludes precise conclusions. Subgroup analyses of both trials indicated that a higher incidence of previous exacerbations was a possible predictor of a better response to treatment. When considered separately or in combination with baseline blood eosinophil count, these factors may identify patients who achieve a greater response with benralizumab.

The results of both trials showed that patients treated with benralizumab experienced statistically significant decreases in asthma symptoms compared with those receiving placebo. A similar improvement was observed with benralizumab in the ACQ-6 and in Standardized Asthma Quality of Life Questionnaire for patients aged 12 years and older (AQLQ[S]+12).

Both the SIROCCO and CALIMA trials met their primary objective and mutually confirmed their respective results. The benefits of benralizumab were observed not only in the reduced frequency of asthma exacerbations, but also in improved lung function and asthma symptoms.

A post hoc subanalysis of both trials assessed the efficacy and safety of benralizumab in patients with eosinophil-driven disease and blood eosinophil counts $<300$ cells $/ \mu \mathrm{L}$ [57]. This analysis compared an eosinophil cut-off count of $\geq 150$ with one of $<150$ cells $/ \mu \mathrm{L}$. The results showed that benralizumab reduced asthma exacerbation rates by $42 \%$ in SIROCCO $(P<.001)$ and $36 \%$ in CALIMA $(P<.001)$ compared with placebo for patients with blood eosinophil counts $\geq 150$ cells $/ \mu \mathrm{L}$. In addition, benralizumab increased prebronchodilator $\mathrm{FEV}_{1}$ (in both studies, $P \leq .002$ ) and improved the total asthma symptom score in $\operatorname{SIROCCO}(P=.009)$ at the end of treatment compared with placebo. The authors concluded that benralizumab is clearly effective in patients with asthma and blood eosinophil counts $\geq 150$ cells $/ \mu \mathrm{L}$ [57].

Another pooled analysis of results from the SIROCCO and CALIMA trials compared the annual exacerbation rate ratio with placebo in subgroups defined by baseline eosinophil counts $(\geq 0, \geq 150, \geq 300$, and $\geq 450$ cells $/ \mu \mathrm{L})$ and by number of exacerbations ( $2 \mathrm{vs} \geq 3$ ) during the year before enrollment [58]. The annual exacerbation rate among patients with baseline blood eosinophil counts $\geq 0$ cells $/ \mu \mathrm{L}$ was 1.16 in patients who received placebo compared with 0.75 in patients who received benralizumab. The reduction rate was greater with increasing blood eosinophil thresholds and with higher numbers of exacerbations. A very recent pooled analysis of the SIROCCO and CALIMA trials evaluated the impact of baseline factors on the efficacy of benralizumab for patients with severe asthma [59]. The results showed that the effect of benralizumab (reduced exacerbation rate, improved lung function, and improved asthma symptoms and control) was enhanced in the overall population and in patients with a baseline eosinophil count $\geq 300$ cells $/ \mu \mathrm{L}$ and the following clinical factors: OCS use, nasal polyposis, prebronchodilator forced vital capacity (FVC) $<65 \%$ of predicted, $\geq 3$ exacerbations in the previous year, and age at diagnosis $\geq 18$ years. In patients with $<300$ cells $/ \mu \mathrm{L}$, OCS use, nasal polyposis, and FVC $<65 \%$ of predicted, the response to benralizumab was better and the exacerbation rate lower. The results of these pooled analyses can help to identify those patients with uncontrolled severe eosinophilic asthma who respond most effectively to benralizumab.

\subsection{ZONDA: Oral Corticosteroid Reduction Trial}

The ZONDA trial included 220 patients with severe asthma associated with eosinophilia and treated with oral corticosteroids [55]. Patients received $8-40 \mathrm{mg} / \mathrm{d}$ of OCS and a regular combination of high-dose ICSs and a LABA, with at least 1 additional drug to maintain asthma control in 53\% of cases. Mean age was 51 years, and $61 \%$ were women. The trial had an 8-week preinclusion period in which OCSs were adjusted to the minimum effective dose without losing asthma control. Patients had a blood eosinophil count $\geq 150$ cells $/ \mu \mathrm{L}$ and a history of at least 1 exacerbation in the previous year. The primary objective of this trial was the percent decrease in the final dose of OCS during weeks 24 to 28 from baseline while maintaining asthma control.

At week 28, benralizumab significantly reduced the median final OCS doses from baseline by $75 \%$, as compared with a reduction of $25 \%$ in the placebo group $(P<.001)$. Moreover, benralizumab administered every 4 weeks resulted in an annual exacerbation rate that was $55 \%$ lower than that of placebo $(P=.003)$, and benralizumab administered every 8 weeks resulted in an annual exacerbation rate that was $70 \%$ 
lower than that of placebo $(P<.001)$. However, lung function $\left(\mathrm{FEV}_{1}\right)$ was not significantly improved in the active treatment group, as compared with the placebo group. Of note, asthma control and health-related quality of life were better in the benralizumab 8 -week dosing regimen ( $P<.05$ vs placebo), but not for the 4-week regimen. With respect to the secondary endpoints in patients who per protocol reached 0 in their dose of OCS (baseline dose $\leq 12.5 \mathrm{mg}$ of prednisone), $52 \%$ of patients in the 8 -week dosing group managed to eliminate systemic corticosteroids, compared with only $19 \%$ in the placebo group. In addition, $59 \%$ of patients managed to maintain an OCS dose $\leq 5 \mathrm{mg} / \mathrm{d}$. In conclusion, patients with severe eosinophilic asthma who received benralizumab subcutaneously every 8 weeks were able to reduce the use of OCS as maintenance treatment while maintaining asthma control [55].

\section{Safety of benralizumab}

The first safety data reported are from a phase 1 trial that evaluated the safety, tolerability, and effects of benralizumab (administered as single-dose intravenous or multiple-dose subcutaneous injections) on eosinophil counts in airway mucosal biopsies of patients with atopic asthma [53]. The incidence of adverse events (AEs) was found to be higher in the benralizumab group than in the placebo group for intravenous dosing (27 vs 17 events, respectively) but not in the multiple subcutaneous dosing group ( $10 \mathrm{vs} 15$ vs 20 events in benralizumab $100 \mathrm{mg}$, benralizumab $200 \mathrm{mg}$, and placebo, respectively) [53]. Of note, at least $1 \mathrm{AE}$ was reported in $100 \%$ of patients who received placebo and in approximately $60 \%$ in the benralizumab group. It could be concluded that none of the AEs reported in this trial seemed to be clearly associated with treatment. In a phase $2 \mathrm{~b}$ dose-ranging study, all AEs and all serious AEs were equally distributed between the placebo and benralizumab groups [56]. Nasopharyngitis was reported by $11 \%$ of patients receiving benralizumab vs $6 \%$ in the placebo group, and injection site reactions occurred in $16 \%$ of patients receiving benralizumab and $4 \%$ receiving placebo.
With respect to the phase 3 trials SIROCCO and CALIMA, the number of AEs and serious AEs did not differ between the placebo and treatment arms. The most frequently reported AEs during treatment with $30 \mathrm{mg}$ of benralizumab every 8 weeks were nasopharyngitis (12-18\%), worsening asthma (11\%), upper respiratory tract infection $(8 \%)$, and headache $(8-9 \%)$ [27,28]. Table 2 shows a comparison of the most common AEs in each study.

The presence of antidrug antibodies was detected in $13 \%$ (SIROCCO) and 15\% (CALIMA) of the patients who received the recommended dosage of benralizumab [27,28]. Most of these antibodies were neutralizing and persistent. Although clearance of benralizumab and the amount of eosinophils in blood was greater in those patients with elevated antidrug antibody titers than in patients without these antibodies, there was no suggestion that positive antidrug antibody response was associated with hypersensitivity or affected efficacy outcomes [27,28].

According to the SIROCCO, CALIMA, and ZONDA studies, the rate of hypersensitivity reactions in patients receiving benralizumab did not differ from that reported for patients receiving placebo. In the SIROCCO trial, the frequency of hypersensitivity reactions was $3 \%$ in both the treated group and the control group; in the CALIMA trial it was $4 \%$ for those who received placebo and $3 \%$ for those who received the recommended dose of benralizumab; and in the ZONDA trial, it was 3\% for those who received the biological drug and $1 \%$ for those who received placebo $[27,28,55]$.

The BORA extension study is a recent randomized, doubleblind, parallel-group, phase 3 extension trial that assessed the long-term safety profile of benralizumab in patients with severe, uncontrolled eosinophilic asthma [60]. All patients who previously participated in and completed the SIROCCO, CALIMA, or ZONDA trials were eligible for enrolment in the BORA study, although the publication only included data from the SIROCCO and CALIMA trials, as the ZONDA study had a different design, was shorter, and had a smaller study population than SIROCCO and CALIMA. Eligible patients had to have completed both trials and remained on subcutaneous

Table 2. Most Frequent Adverse Reactions During Treatment With Benralizumab 30 mg Every 8 Weeks in Patients With Severe Uncontrolled Eosinophilic Asthma

\begin{tabular}{|c|c|c|c|c|c|c|}
\hline & \multicolumn{2}{|c|}{ SIROCCO [28] } & \multicolumn{2}{|c|}{ CALIMA [27] } & \multicolumn{2}{|c|}{ BORA [60] } \\
\hline & PCB & $\mathrm{B}$ & PCB & $\mathrm{B}$ & PCB & $\mathrm{B}$ \\
\hline Worsening asthma & $19 \%$ & $11 \%$ & $15 \%$ & $11 \%$ & $7 \%$ & $8 \%$ \\
\hline Nasopharyngitis & $12 \%$ & $12 \%$ & $21 \%$ & $18 \%$ & - & - \\
\hline Upper respiratory tract infection & $9 \%$ & $8 \%$ & $9 \%$ & $8 \%$ & $15 \%$ & $16 \%$ \\
\hline Headache & $5 \%$ & $9 \%$ & $7 \%$ & $8 \%$ & $3 \%$ & $6 \%$ \\
\hline Bronchitis & $7 \%$ & $5 \%$ & $12 \%$ & $10 \%$ & $5 \%$ & $6 \%$ \\
\hline Sinusitis & $7 \%$ & $6 \%$ & $8 \%$ & $5 \%$ & $5 \%$ & $5 \%$ \\
\hline Influenza & $6 \%$ & $5 \%$ & $5 \%$ & $3 \%$ & $1 \%$ & $0 \%$ \\
\hline Pharyngitis & $3 \%$ & $6 \%$ & $2 \%$ & $2 \%$ & - & - \\
\hline Injection site reactions & $2 \%$ & $2 \%$ & $2 \%$ & $2 \%$ & $1 \%$ & $2 \%$ \\
\hline
\end{tabular}

Abbreviations: B, benralizumab; PCB, placebo 
benralizumab $30 \mathrm{mg}$ every 4 or 8 weeks. Patients who had received placebo in those trials were rerandomized at a 1:1 ratio to benralizumab $30 \mathrm{mg}$ every 4 weeks or every 8 weeks. The full analysis set included 1576 patients: 783 who received benralizumab every 4 weeks (including 265 newly assigned patients) and 793 who received benralizumab every 8 weeks (including 281 newly assigned patients). After 1 year of treatment, the most common adverse events in both treatment groups that led to treatment discontinuation were viral upper respiratory tract infection (14\%-16\%) and worsening asthma (7\%-10\%), and the most common serious AEs were worsening asthma $(3 \%-4 \%)$ and pneumonia $(\leq 1 \%)$. The percentage of patients who received benralizumab and who experienced an AE was similar between SIROCCO or CALIMA (71-75\%) and BORA (65-71\%), as was the percentage of patients who had an AE that led to treatment discontinuation $(2 \%$ in SIROCCO and CALIMA vs $2-3 \%$ in BORA). The results of the BORA study support the administration of benralizumab for 2 years, with a safety and tolerability profile similar to that observed over 1 year in the SIROCCO and CALIMA trials.

Although elimination of eosinophils due to anti-IL-5 treatment may have some impact on host defense (eg, against parasitic infections), further studies and clinical observation in this area are needed, as patients with known helminthic infections were excluded from participation in clinical trials. Nevertheless, no cases of helminth infection were reported in the BORA study [60].

\section{Ongoing research}

Numerous ongoing studies are evaluating the efficacy and safety of benralizumab in the treatment of patients with uncontrolled severe asthma and eosinophilic inflammation. Some of them are still recruiting patients. Table 3 shows a brief summary of each one. Except for the MELTEMI study, all of the studies are randomized phase 3 placebo-controlled trials.

Other ongoing trials are assessing benralizumab in the treatment of other conditions, such as eosinophilic granulomatosis with polyangiitis (BITE study, phase 2, NCT03010436), severe nasal polyposis (OSTRO study, phase 3, NCT03401229), and eosinophilic gastritis (phase 1/2, NCT03473977). These studies are still recruiting patients.

Results were reported at the 2018 American Academy of Allergy, Asthma \& Immunology/World Allergy Organization (AAAAI/WAO) Joint Congress [61,62]. A post hoc pooled analysis of the SIROCO and CALIMA trials showed that benralizumab demonstrated enhanced clinical efficacy for patients with severe, uncontrolled eosinophilic asthma and nasal polyposis [61]. The rationale for this study is that nasal polyposis has been associated with an eosinophilic asthma phenotype and may predict the efficacy of benralizumab. Compared with placebo, benralizumab reduced exacerbation rates by $42 \%$ in patients with nasal polyposis and by $38 \%$ in patients without nasal polyposis. In addition, benralizumab increased prebronchodilator $\mathrm{FEV}_{1}$ by $0.272 \mathrm{~L}$ in patients

Table 3. Ongoing Phase III Studies With Benralizumab

\begin{tabular}{lcccl}
$\begin{array}{l}\text { Study } \\
\text { (Start Date) }\end{array}$ & $\begin{array}{c}\text { ClinicalTrials.gov } \\
\text { Identifier }\end{array}$ & $\begin{array}{c}\text { Treatment } \\
\text { Arms }\end{array}$ & $\begin{array}{c}\text { Actual } \\
\text { Enrollment }\end{array}$ & Objective \\
\hline $\begin{array}{l}\text { MELTEMI } \\
\text { (June 22, 2016) }\end{array}$ & NCT02808819 & Benralizumab & 446 & $\begin{array}{l}\text { To continue to characterize the safety profile of benralizumab } \\
\text { and monitor the pharmacodynamic activity of the drug in those } \\
\text { asthma patients who remain on treatment for at least 16 weeks } \\
\text { and not more than 40 weeks in the predecessor BORA study. }\end{array}$ \\
$\begin{array}{l}\text { ARIA } \\
\text { (July 1, 2016) }\end{array}$ & NCT02821416 & $\begin{array}{c}\text { Benralizumab } \\
\text { vs placebo }\end{array}$ & $\begin{array}{c}45 \\
\text { (still } \\
\text { recruiting) }\end{array}$ & $\begin{array}{l}\text { Tovaluate the effect of a fixed 30-mg dose of benralizumab } \\
\text { administered subcutaneously every 4 weeks on allergen-induced } \\
\text { inflammation in patients with mild atopic asthma challenged } \\
\text { with an inhaled allergen. }\end{array}$
\end{tabular}

SOLANA

(August 17, 2016)
NCT02869438

Benralizumab

235
vs placebo

To investigate the onset and maintenance of the effect of benralizumab on lung function, blood eosinophils, asthma control metrics and quality of life during 12-week treatment in patients with uncontrolled, severe asthma with eosinophilic inflammation. A subset of patients will take part in a body plethysmography substudy to further investigate the effect on lung function.

\begin{tabular}{|c|c|c|c|c|}
\hline $\begin{array}{l}\text { ANDHI } \\
\text { (May 31, 2017) }\end{array}$ & NCT03170271 & $\begin{array}{l}\text { Benralizumab } \\
\text { vs placebo }\end{array}$ & $\begin{array}{c}630 \\
\text { (still } \\
\text { recruiting) }\end{array}$ & $\begin{array}{l}\text { To investigate the effect of benralizumab on the rate of asthma } \\
\text { exacerbations, patient-reported quality of life and lung function } \\
\text { during the } 24 \text {-week treatment in patients with uncontrolled, } \\
\text { severe asthma with an eosinophilic phenotype. A subset of } \\
\text { patients will be assessed for their ongoing chronic } \\
\text { rhinosinusitis with nasal polyps. }\end{array}$ \\
\hline $\begin{array}{l}\text { MIRACLE } \\
\text { (June 14, 2017) }\end{array}$ & NCT03186209 & $\begin{array}{l}\text { Benralizumab } \\
\text { vs placebo }\end{array}$ & $\begin{array}{l}666 \\
\text { (still } \\
\text { recruiting) }\end{array}$ & $\begin{array}{l}\text { To evaluate the efficacy and safety of a fixed } 30 \mathrm{mg} \text { dose } \\
\text { of benralizumab administered subcutaneously for patients with } \\
\text { a history of asthma exacerbations and uncontrolled asthma } \\
\text { receiving medium to high-dose ICSs plus a LABA with or } \\
\text { without OCSs and additional asthma controllers. }\end{array}$ \\
\hline
\end{tabular}

Abbreviations: ICS, inhaled corticosteroid; LABA, long-acting $\beta_{2}$-agonist; OCS, oral corticosteroid. 
with nasal polyposis and by $0.102 \mathrm{~L}$ in patients without nasal polyposis. Similar trends were observed for efficacy measures of asthma symptoms (ACQ-6) and asthma-related quality of life (AQLQ[S]+12) [61]. Benralizumab also proved to be effective in hypereosinophilic syndrome with gastrointestinal involvement, a disease characterized by gastrointestinal eosinophilia and a peripheral eosinophil count $\geq 1500$ cells/ $\mathrm{mm}^{3}$ that does not always respond to corticosteroids or dietary intervention [62]. After 24 weeks of treatment with benralizumab, a dramatic reduction in eosinophil count was observed, and gastrointestinal symptoms improved in most patients [62].

\section{Conclusions}

Benralizumab is a monoclonal antibody against IL-5R $\alpha$ that has proven to be effective and safe in the treatment of adults with uncontrolled severe eosinophilic asthma despite using high-dose ICSs and a LABA. Unlike other treatments targeting the IL-5 pathway used to manage eosinophilic asthma, benralizumab can reduce the activation and differentiation of eosinophils and basophils by preventing IL-5 from binding to its receptor and inducing apoptosis of these cells. These 2 functions are responsible for the rapid and almost complete decrease in eosinophil and basophil counts, which is greater than that described for mepolizumab and reslizumab. The decrease in blood eosinophils is accompanied not only by significantly reduced asthma exacerbations and use of OCSs, but also by improved lung function, asthma symptoms, asthma control, and quality of life, especially in patients with a baseline eosinophil count $\geq 300$ cells $/ \mu \mathrm{L}$ and a higher incidence of previous exacerbations. These results will be helpful in identifying patients with uncontrolled severe eosinophilic asthma who respond most effectively to benralizumab. These benefits were reached more quickly and with a longer dosing interval (every 8 weeks) than with mepolizumab or reslizumab. Benralizumab can be considered an effective and safe alternative in the treatment of patients with severe eosinophilic asthma. It could also be a possible treatment in other diseases involving eosinophils. Finally, the use of benralizumab in real life will provide new insights into the role of eosinophils in the body.

\section{Acknowledgments}

The authors wish to thank Dr. Fernando Sánchez Barbero and Content Ed Net (Madrid, Spain) for writing and editorial support during the preparation of this manuscript.

\section{Funding}

AstraZeneca Farmacéutica Spain S.A. funded medical writing support but made no contribution the contents or decision to publish.

\section{Conflicts of Interest}

Ignacio Dávila González has received payment for lectures from Allergy Therapeutics, ALK-Abelló, AstraZeneca, Diater,
GlaxoSmithKline, Leti, Merck, Novartis, Stallergenes, and Teva. He has also received remuneration for providing consultancy services from ALK-Abelló, AstraZeneca, GlaxoSmithKline, Merck, Novartis, Sanofi, and Stallergenes, as well as grants from Merck and Thermo Fisher Diagnostics.

Francisco Moreno Benítez has received payment for lectures or advisory services from AstraZeneca, Stallergenes, ALK-Abello, and Allergy Therapeutics.

Santiago Quirce has served as a consultant for AstraZeneca, Novartis, Sanofi, Teva, ALK-Abelló, Mundipharma, Boehringer Ingelheim, and GlaxoSmithKline and has received lecture fees from Chiesi, Novartis, GlaxoSmithKline, Leti, AstraZeneca, and Mundipharma.

\section{References}

1. Global Initiative for Asthma. 2018 GINA Report. Global Strategy for Asthma Management and Prevention [cited 2018 September 9]. Available from: http://www.ginasthma.org.

2. Guía Española para el Manejo del Asma v4.3 [cited 2018 September 9]. Available from: https://www.gemasma.com/.

3. Wenzel SE. Asthma phenotypes: the evolution from clinical to molecular approaches. Nat Med. 2012;18:716-25.

4. Levine SJ, Wenzel SE. Narrative review: the role of Th2 immune pathway modulation in the treatment of severe asthma and its phenotypes. Ann Intern Med. 2010;152:232-7.

5. Barnes PJ. Pathophysiology of allergic inflammation. Immunol Rev. 2011;242:31-50

6. Yu S, Kim HY, Chang YJ, DeKruyff RH, Umetsu DT. Innate lymphoid cells and asthma. J Allergy Clin Immunol. 2014;133:943-50; quiz 51.

7. Lambrecht BN, Hammad H. The immunology of asthma. Nat Immunol. 2015;16:45-56.

8. Lloyd CM, Snelgrove RJ. Type 2 immunity: Expanding our view. Sci Immunol. 2018;3.

9. Taylor DR, Bateman ED, Boulet LP, Boushey HA, Busse WW, Casale TB, et al. A new perspective on concepts of asthma severity and control. Eur Respir J. 2008;32:545-54.

10. Chung KF, Wenzel SE, Brozek JL, Bush A, Castro M, Sterk PJ, et al. International ERS/ATS guidelines on definition, evaluation and treatment of severe asthma. Eur Respir J. 2014;43:34373.

11. Quirce S, Plaza V, Picado C, Vennera M, Casafont J. Prevalence of uncontrolled severe persistent asthma in pneumology and allergy hospital units in Spain. J Investig Allergol Clin Immunol. 2011;21:466-71.

12. Moore WC, Meyers DA, Wenzel SE, Teague WG, Li H, Li X, et al. Identification of asthma phenotypes using cluster analysis in the Severe Asthma Research Program. Am J Respir Crit Care Med. 2010;181:315-23.

13. Haldar P, Pavord ID, Shaw DE, Berry MA, Thomas M, Brightling $\mathrm{CE}$, et al. Cluster analysis and clinical asthma phenotypes. Am J Respir Crit Care Med. 2008;178:218-24.

14. Siroux V, Basagaña X, Boudier A, Pin I, García-Aymerich J, Vesin $A$, et al. Identifying adult asthma phenotypes using a clustering approach. Eur Respir J. 2011;38:310-7.

15. Anderson GP. Endotyping asthma: new insights into key pathogenic mechanisms in a complex, heterogeneous disease. Lancet. 2008;372:1107-19. 
16. Pavord ID, Korn S, Howarth P, Bleecker ER, Buhl R, Keene ON, et al. Mepolizumab for severe eosinophilic asthma (DREAM): a multicentre, double-blind, placebo-controlled trial. Lancet. 2012;380:651-9.

17. Ortega H, Chupp G, Bardin P, Bourdin A, Garcia G, Hartley $B$, et al. The role of mepolizumab in atopic and nonatopic severe asthma with persistent eosinophilia. Eur Respir J. 2014;44:239-41.

18. Ortega $H G$, Liu MC, Pavord ID, Brusselle GG, FitzGerald JM, Chetta $A$, et al. Mepolizumab treatment in patients with severe eosinophilic asthma. N Engl J Med. 2014;371:1198-207.

19. Ortega HG, Yancey SW, Mayer B, Gunsoy NB, Keene ON, Bleecker ER, et al. Severe eosinophilic asthma treated with mepolizumab stratified by baseline eosinophil thresholds: a secondary analysis of the DREAM and MENSA studies. Lancet Respir Med. 2016;4:549-56.

20. Bel EH, Wenzel SE, Thompson PJ, Prazma CM, Keene ON, Yancey SW, et al. Oral glucocorticoid-sparing effect of mepolizumab in eosinophilic asthma. N Engl J Med. 2014;371:1189-97.

21. Lugogo N, Domingo C, Chanez P, Leigh R, Gilson MJ, Price $R G$, et al. Long-term efficacy and safety of mepolizumab in patients with severe eosinophilic asthma: A multi-center, open-label, phase iiib study. Clin Ther. 2016;38:2058-70 e1.

22. Murphy K, Jacobs J, Bjermer L, Fahrenholz JM, Shalit $Y$, Garin $M$, et al. Long-term safety and efficacy of reslizumab in patients with eosinophilic asthma. J Allergy Clin Immunol Pract. 2017:5:1572-81 e3.

23. Castro M, Zangrilli J, Wechsler ME, Bateman ED, Brusselle GG, Bardin P, et al. Reslizumab for inadequately controlled asthma with elevated blood eosinophil counts: results from two multicentre, parallel, double-blind, randomised, placebocontrolled, phase 3 trials. Lancet Respir Med. 2015;3:355-66.

24. Corren J, Weinstein S, Janka L, Zangrilli J, Garin M. Phase 3 study of reslizumab in patients with poorly controlled asthma: Effects across a broad range of eosinophil counts. Chest. 2016;150:799-810.

25. Bjermer L, Lemiere C, Maspero J, Weiss S, Zangrilli J, Germinaro M. Reslizumab for inadequately controlled asthma with elevated blood eosinophil levels: A randomized phase 3 study. Chest. 2016;150:789-98.

26. Brusselle G, Germinaro M, Weiss S, Zangrilli J. Reslizumab in patients with inadequately controlled late-onset asthma and elevated blood eosinophils. Pulm Pharmacol Ther. 2017;43:3945.

27. FitzGerald JM, Bleecker ER, Nair P, Korn S, Ohta K, Lommatzsch $M$, et al. Benralizumab, an anti-interleukin-5 receptor alpha monoclonal antibody, as add-on treatment for patients with severe, uncontrolled, eosinophilic asthma (CALIMA): a randomised, double-blind, placebo-controlled phase 3 trial. Lancet. 2016;388:2128-41.

28. Bleecker ER, FitzGerald JM, Chanez P, Papi A, Weinstein SF, Barker $\mathrm{P}$, et al. Efficacy and safety of benralizumab for patients with severe asthma uncontrolled with high-dosage inhaled corticosteroids and long-acting beta2-agonists (SIROCCO): a randomised, multicentre, placebo-controlled phase 3 trial. Lancet. 2016;388:2115-27.

29. Bousquet J, Chanez P, Lacoste JY, Barneon G, Ghavanian N, Enander I, et al. Eosinophilic inflammation in asthma. N Engl J Med. 1990;323:1033-9.
30. Aleman F, Lim HF, Nair P. Eosinophilic endotype of asthma. Immunol Allergy Clin North Am. 2016;36:559-68.

31. Buhl R, Humbert M, Bjermer L, Chanez P, Heaney LG, Pavord I, et al. Severe eosinophilic asthma: a roadmap to consensus. Eur Respir J. 2017;49.

32. Schleich FN, Chevremont $A$, Paulus V, Henket $M$, Manise $M$, Seidel $L$, et al. Importance of concomitant local and systemic eosinophilia in uncontrolled asthma. Eur Respir J. 2014;44:97108.

33. Wagener AH, de Nijs SB, Lutter R, Sousa AR, Weersink EJ, Bel $E H$, et al. External validation of blood eosinophils, FE(NO) and serum periostin as surrogates for sputum eosinophils in asthma. Thorax. 2015;70:115-20.

34. Akar HH, Tahan F, Gungor HE. The association of forced expiratory volume in one second and forced expiratory flow at $50 \%$ of the vital capacity, peak expiratory flow parameters, and blood eosinophil counts in exercise-induced bronchospasm in children with mild asthma. Asia Pac Allergy. 2015;5:98-102.

35. Malinovschi A, Janson C, Borres M, Alving K. Simultaneously increased fraction of exhaled nitric oxide levels and blood eosinophil counts relate to increased asthma morbidity. J Allergy Clin Immunol. 2016;138:1301-8 e2.

36. Price D, Wilson AM, Chisholm A, Rigazio A, Burden A, Thomas $M$, et al. Predicting frequent asthma exacerbations using blood eosinophil count and other patient data routinely available in clinical practice. J Asthma Allergy. 2016;9:1-12.

37. Fowler SJ, Tavernier G, Niven R. High blood eosinophil counts predict sputum eosinophilia in patients with severe asthma. J Allergy Clin Immunol. 2015;135:822-4 e2.

38. Álvarez Puebla MJ, Aroabarren Aleman E, Corcuera García A, Ibañez Bereiz B, Iraola Iribar A, Olaguibel Rivera JM. Blood eosinophils, fraction of exhaled nitric oxide, and serum eosinophil cationic protein as surrogate markers for sputum eosinophils in asthma: Influence of treatment with inhaled corticosteroids. J Investig Allergol Clin Immunol. 2018;28:2102.

39. Varricchi G, Bagnasco D, Borriello F, Heffler E, Canonica GW. Interleukin-5 pathway inhibition in the treatment of eosinophilic respiratory disorders: evidence and unmet needs. Curr Opin Allergy Clin Immunol. 2016;16:186-200.

40. Sastre B, Rodrigo-Muñoz JM, García-Sánchez DA, Cañas JA, del Pozo V. Eosinophils: Old players in a new game. J Investig Allergol Clin Immunol. 2018;28:289-304.

41. Smith SG, Chen R, Kjarsgaard M, Huang C, Oliveria JP, O'Byrne $P M$, et al. Increased numbers of activated group 2 innate lymphoid cells in the airways of patients with severe asthma and persistent airway eosinophilia. J Allergy Clin Immunol. 2016;137:75-86 e8.

42. Rosenberg HF, Phipps S, Foster PS. Eosinophil trafficking in allergy and asthma. J Allergy Clin Immunol. 2007;119:130310; quiz 11-2.

43. Saglani S, Lloyd CM. Eosinophils in the pathogenesis of paediatric severe asthma. Curr Opin Allergy Clin Immunol. 2014; 14:143-8.

44. Molfino NA, Gossage D, Kolbeck R, Parker JM, Geba GP. Molecular and clinical rationale for therapeutic targeting of interleukin-5 and its receptor. Clin Exp Allergy. 2012;42:71237. 
45. Hamid Q, Azzawi M, Ying S, Mogbel R, Wardlaw AJ, Corrigan $C J$, et al. Expression of mRNA for interleukin-5 in mucosal bronchial biopsies from asthma. J Clin Invest. 1991;87:15416.

46. Fulkerson PC, Rothenberg ME. Targeting eosinophils in allergy, inflammation and beyond. Nat Rev Drug Discov. 2013;12:11729.

47. Technical information beralizumab (Fasenra ${ }^{\circledR}$, Astrazeneca) [cited 2018 August 14]. Available from: http://www.ema. europa.eu/docs/en_GB/document_library/EPAR_-_Product_ Information/human/004433/WC500245331.pdf.

48. Kupczyk M, Kuna P. Benralizumab: an anti-IL-5 receptor alpha monoclonal antibody in the treatment of asthma. Immunotherapy. 2018;10:349-59.

49. Kolbeck R, Kozhich A, Koike M, Peng L, Andersson CK, Damschroder MM, et al. MEDI-563, a humanized anti-IL-5 receptor alpha $\mathrm{mAb}$ with enhanced antibody-dependent cell-mediated cytotoxicity function. J Allergy Clin Immunol. 2010;125:1344-53 e2.

50. Busse WW, Katial R, Gossage D, Sari S, Wang B, Kolbeck R, et al. Safety profile, pharmacokinetics, and biologic activity of MEDI-563, an anti-IL-5 receptor alpha antibody, in a phase I study of subjects with mild asthma. J Allergy Clin Immunol. 2010;125:1237-44 e2.

51. Nowak RM, Parker JM, Silverman RA, Rowe BH, Smithline $H$, Khan $F$, et al. A randomized trial of benralizumab, an antiinterleukin 5 receptor alpha monoclonal antibody, after acute asthma. Am J Emerg Med. 2015;33:14-20.

52. Pham TH, Damera G, Newbold P, Ranade K. Reductions in eosinophil biomarkers by benralizumab in patients with asthma. Respir Med. 2016:111:21-9.

53. Laviolette M, Gossage DL, Gauvreau G, Leigh R, Olivenstein R, Katial $R$, et al. Effects of benralizumab on airway eosinophils in asthmatic patients with sputum eosinophilia. J Allergy Clin Immunol. 2013;132:1086-96 e5.

54. Sehmi R, Lim HF, Mukherjee M, Huang C, Radford K, Newbold $P$, et al. Benralizumab attenuates airway eosinophilia in prednisone-dependent asthma. J Allergy Clin Immunol. 2018;141:1529-32 e8.

55. Nair P, Wenzel S, Rabe KF, Bourdin A, Lugogo NL, Kuna P, et al. Oral glucocorticoid-sparing effect of benralizumab in severe asthma. N Engl J Med. 2017;376:2448-58.

56. Castro M, Wenzel SE, Bleecker ER, Pizzichini E, Kuna P, Busse WW, et al. Benralizumab, an anti-interleukin 5 receptor alpha monoclonal antibody, versus placebo for uncontrolled eosinophilic asthma: a phase $2 \mathrm{~b}$ randomised dose-ranging study. Lancet Respir Med. 2014;2:879-90.

57. Goldman M, Hirsch I, Zangrilli JG, Newbold P, Xu X. The association between blood eosinophil count and benralizumab efficacy for patients with severe, uncontrolled asthma: subanalyses of the Phase III SIROCCO and CALIMA studies. Curr Med Res Opin. 2017;33:1605-13.

58. FitzGerald JM, Bleecker ER, Menzies-Gow A, Zangrilli JG, Hirsch I, Metcalfe $P$, et al. Predictors of enhanced response with benralizumab for patients with severe asthma: pooled analysis of the SIROCCO and CALIMA studies. Lancet Respir Med. 2018;6:51-64.

59. Bleecker ER, Wechsler ME, FitzGerald JM, Menzies-Gow A Wu Y, Hirsch I, et al. Baseline patient factors impact on the clinical efficacy of benralizumab for severe asthma. Eur Respir J. 2018;52.

60. Busse WW, Bleecker ER, FitzGerald JM, Ferguson GT, Barker $P_{1}$ Sproule $S$, et al. Long-term safety and efficacy of benralizumab in patients with severe, uncontrolled asthma: 1-year results from the BORA phase 3 extension trial. Lancet Respir Med. 2018:[Epub ahead of print].

61. Maspero J, Harrison T, Werkström V, Wu Y, Gopalan G, Zangrilli J. Clinical efficacy of benralizumab in patients with severe, uncontrolled eosinophilic asthma and nasal polyposis: Pooled analysis of the SIROCCO and CALIMA trials. J Allergy Clin Immunol. 2018:141:AB12.

62. Kuang FL, Alao H, Kumar S, Powers A, Quezado M, Wang Z, et al. Benralizumab (anti-IL5R $\alpha$ ) depletes gut tissue eosinophilia and improves symptoms in hypereosinophilic syndrome with gastrointestinal involvement. J Allergy Clin Immunol. 2018:141:AB196.

\section{Francisco Moreno Benítez}

Unidad de Inmunología y Alergia

Clínica Lobatón

Avda. Fernández Ladreda, 9

11008 Cádiz, Spain

E-mail: dr.moreno@drlobaton.com 